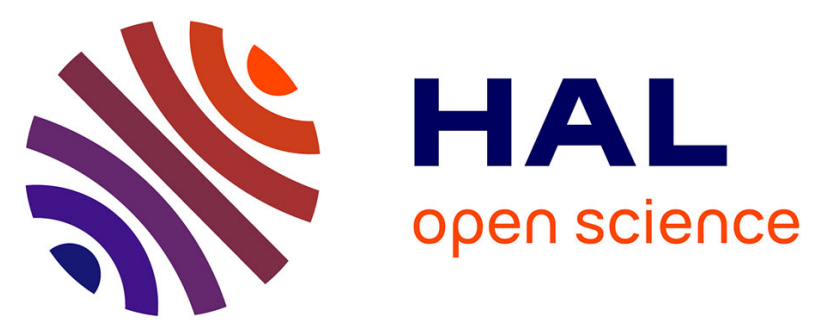

\title{
Characterization of some monooxygenase activities and solubilization of hepatic cyctochrome P-450 in two species of freshwater fish, the nase (Chondrostoma nasus) and the roach (Rutilus rutilus)
}

Gilles Monod, Alain Devaux, Jean-Louis Riviere

\section{To cite this version:}

Gilles Monod, Alain Devaux, Jean-Louis Riviere. Characterization of some monooxygenase activities and solubilization of hepatic cyctochrome P-450 in two species of freshwater fish, the nase (Chondrostoma nasus) and the roach (Rutilus rutilus). Comparative Biochemistry and Physiology - Part C: Comparative Pharmacology and Toxicology, 1987, 88 (1), pp.83-89. 10.1016/0742-8413(87)90050-8 . hal-02728829

\section{HAL Id: hal-02728829 \\ https://hal.inrae.fr/hal-02728829}

Submitted on 2 Jun 2020

HAL is a multi-disciplinary open access archive for the deposit and dissemination of scientific research documents, whether they are published or not. The documents may come from teaching and research institutions in France or abroad, or from public or private research centers.
L'archive ouverte pluridisciplinaire HAL, est destinée au dépôt et à la diffusion de documents scientifiques de niveau recherche, publiés ou non, émanant des établissements d'enseignement et de recherche français ou étrangers, des laboratoires publics ou privés. 


\title{
CHARACTERIZATION OF SOME MONOOXYGENASE ACTIVITIES AND SOLUBILIZATION OF HEPATIC CYTOCHROME P-450 IN TWO SPECIES OF FRESHWATER FISH, THE NASE (CHONDROSTOMA NASUS) AND THE ROACH (RUTILUS RUTILUS)*
}

\author{
G. Monod, A. Devaux and J. L. Rivière \\ Institut National de la Recherche Agronomique, Laboratoire d'Ecotoxicologie INRA-ENVL, BP 31, \\ 69752 Charbonnières Cedex, France
}

(Received 10 November 1986)

\begin{abstract}
Hepatic monooxygenase activities were studied in microsomal fractions from two species of freshwater fish, the nase (Chondrostoma nasus) and the European roach (Rutilus rutilus).

2. These activities were determined by using four substrates, 7-ethoxycoumarin, 7-ethoxyresorufin, benzo(a)pyrene, and 2,5-diphenyloxazole and were characterized according to $\mathrm{pH}$, temperature, cofactors, and the differential effects of two inhibitors, metyrapone and $\alpha$-naphthoflavone.

3. Solubilization of microsomes was achieved by the use of detergents, with a good recovery of the cytochrome P-450.
\end{abstract}

\section{INTRODUCTION}

Hepatic cytochrome P-450-dependent monooxygenases (MO) are involved in the metabolism of both endogenous substrates (such as steroids, fatty acids, bile acids) and exogenous substances (such as drugs, pesticides, polycyclic aromatic hydrocarbons; Estabrook et al., 1979). The study of these enzymes in non-mammalian species is relevant to a number of questions, including the nature and the catalytic activities of the different forms of cytochrome P-450 present in liver and extrahepatic organs, and the effects of these enzyme systems in the activation and detoxication of pollutants.

Their existence in fish liver is now well established (Chambers and Yarbrough, 1976; James et al., 1977; Bend and James, 1978; Lech and Bend, 1980). However, while MO activities of marine species and various trouts have received considerable attention, few detailed studies have been done on other freshwater species.

The present work was undertaken to investigate the MO activities in the liver of two species of freshwater fish, the nase (Chondrostoma nasus) and the roach (Rutilus rutilus) commonly found in the river Rhône. The selected substrates, 7-ethoxycoumarin, 7-ethoxyresorufin, benzo(a)pyrene, and 2,5-diphenyloxazole have been extensively used in mammals. We characterize here the in vitro metabolism of these substrates according to $\mathrm{pH}$, temperature, cofactor requirements, and the inhibitory effects of two diagnostic inhibitors, metyrapone and $\alpha$-naphthoflavone. Furthermore, this study examines the effects of ionic and non-ionic detergents that have

*These data were presented, in part, at the 10th Drug Metabolism Workshop, July 1985, Guildford, UK. been used for the solubilization of liver microsomes from different animal species.

\section{MATERIALS AND METHODS}

\section{Animals}

Fish were caught with a net and dissected live shortly after collection. Each liver was removed, wrapped in aluminium foil, and frozen in liquid nitrogen until processed for the preparation of microsomes. Adult male OFA rats (150-180 g) from IFFA-Credo (L'Arbesle, France) were used for comparison.

\section{Preparation of microsomes}

Fish and rat livers were homogenized in $0.15 \mathrm{M} \mathrm{KCl}$, $50 \mathrm{mM}$ phosphate buffer, $\mathrm{pH} 7.4$, using a Potter-Elvehjem homogenizer with three passes of a motor-driven Teflon pestle. The tissue homogenate was centrifuged in a Beckman $\mathrm{J}-21 \mathrm{C}$ centrifuge for $15 \mathrm{~min}$ at $10,000 \mathrm{~g}$ at $+4^{\circ} \mathrm{C}$. The supernatant was then recentrifuged in a Beckman L8-55 ultracentrifuge for $60 \mathrm{~min}$ at $105,000 \mathrm{~g}$ at $+4^{\circ} \mathrm{C}$. The microsomal pellet was resuspended in $50 \mathrm{mM}$ phosphate buffer, $\mathrm{pH} 7.4$, containing $1 \mathrm{mM}$ DTT, $1 \mathrm{mM}$ EDTA, $20 \%$ glycerol, and stored in small aliquots at $-80^{\circ} \mathrm{C}$. When maintained at this temperature, there was no loss in monooxygenase activities over several months.

\section{Chemicals}

Glucose 6-phosphate (G 6-P), glucose 6-phosphate deshydrogenase (G 6-PDH), reduced nicotinamide adenine dinucleotide (NADH), nicotinamide adenine dinucleotide phosphate (NADP), reduced nicotinamide adenine dinucleotide phosphate (NADPH), and dithiothreitol (DTT) were purchased from Boehringer-Mannheim, France. 7-Ethoxycoumarin was synthesized by the method of Ullich and Weber (1972). 7-Ethoxyresorufin (7-ethoxyphenoxazone) was synthesized by the method of Prough et al. (1978) from resorufin (7-hydroxyphenoxazone, Eastman Organic Chemicals, Rochester, NY). $\alpha$-Naphthoflavone (7,8-benzoflavone) and metyrapone were from Aldrich, France. Emulgen 911 and 913 , and Renex 690 were 
Table 1. Components of the monooxygenase system and monooxygenase activities in hepatic microsomal fractions from nase and

\begin{tabular}{lcc} 
& roach & \\
\hline & Nase & Roach \\
\hline $\begin{array}{l}\text { Protein* } \\
\text { (mg/g liver). }\end{array}$ & 21.2 & 18.8 \\
$\begin{array}{l}\text { Cytochrome P-450 } \\
\text { (nmol/mg protein). }\end{array}$ & 0.58 & 0.36 \\
$\begin{array}{l}\text { NADPH-cytochrome c reductase } \\
\text { (nmol/mg protein/min). }\end{array}$ & 40 & 30 \\
$\begin{array}{l}\text { 7-ECOD } \\
\text { (pmol/mg protein/min). }\end{array}$ & 180 & 68 \\
$\begin{array}{l}\text { 7-EROD } \\
\text { (pmol/mg protein/min). }\end{array}$ & 79 & 44 \\
$\begin{array}{l}\text { AHH } \\
\text { (FU/mg protein/min). }\end{array}$ & 125 & 69 \\
$\begin{array}{l}\text { PPOH } \\
\text { (FU/mg protein/min). }\end{array}$ & 0.183 & 0.123 \\
\hline
\end{tabular}

obtained from Kao-Atlas, France. Sodium cholate and Lubrol PX were from Sigma (St Louis, USA). CHAPS \{3-[(3-cholamidopropyl)dimethylammonio]-1-propanesulfonate\} was from Boehringer-Mannheim, France. Other analytical grade chemicals were commercially purchased.

\section{Enzyme assays}

The studied reactions were benzo(a)pyrene hydroxylase (AHH), 2,5-diphenyloxazole hydroxylase $(\mathrm{PPOH})$, 7-ethoxycoumarin $O$-deethylase (7-ECOD), and 7-ethoxyresorufin $O$-deethylase (7-EROD). Activity was assayed in a final volume of $1 \mathrm{ml}$ containing $0.1 \mathrm{M}$ phosphate buffer, $\mathrm{pH} 7.4,0.5 \mathrm{mM}$ NADP, $5 \mathrm{mM} \mathrm{G} 6-\mathrm{P}, 1$ unit/ml G 6-PDH, microsomal protein, and substrate. The concentration of substrates were: benzo(a)pyrene (added in $40 \mu \mathrm{l}$ methanol) $0.080 \mathrm{mM}$, 7-ethoxycoumarin (added in water) $0.1 \mathrm{mM}, 7$-ethoxyresorufin (added in $10 \mu 1$ methoxyethanol) $1 \mu \mathrm{M}$, and 2,5-diphenyloxazole (added in $10 \mu 1$ methanol) $100 \mu \mathrm{M}$. Unless otherwise stated, all activities were performed at environmental temperature $\left(+10^{\circ} \mathrm{C}\right)$ during $1 \mathrm{~min}$ (7-EROD), $10 \mathrm{~min}$ (7-ECOD) or $15 \mathrm{~min}$ (AHH and $\mathrm{PPOH}$ ). Reactions were stopped by $1 \mathrm{ml}$ acetone (AHH and $\mathrm{PPOH}), 100 \mu 1$ trichloracetic acid $(20 \% ; 7-\mathrm{ECOD})$ or $2 \mathrm{ml}$ acetone (7-EROD). Hydroxylated metabolites of benzo(a)pyrene and 2,5-diphenyloxazole were extracted according to Nebert and Gelboin (1968) and assayed fluorometrically at excitation wavelength $395 \mathrm{~nm}$ and emission wavelength $522 \mathrm{~nm}(\mathrm{AHH})$, and excitation wavelength $345 \mathrm{~nm}$ and emission wavelength $510 \mathrm{~nm}(\mathrm{PPOH})$. Results were expressed in relative fluorescence units (FU) where 1 FU equals the fiuorescence of a quinine sulfate solution $(1 \mu \mathrm{g} / \mathrm{ml})$ at these same wavelengths. The fluorescence of 7-hydroxycoumarin was measured (excitation wavelength: $380 \mathrm{~nm}$; emission wavelength: $480 \mathrm{~nm}$ ) after extraction of the product by ethyl acetate $(4 \mathrm{ml})$ and mixing $1 \mathrm{ml}$ of organic phase with $1 \mathrm{ml}$ of ethanol and $1 \mathrm{ml}$ of glycine buffer (pH 10.4) The fluorescence of resorufin was measured according to the method of Rifkind and Muschick (1983). Fluorometer was standardized by 7 -hydroxycoumarin (7-ECOD) and resorufin (7-EROD).

NADPH-cytochrome $c$ reductase activity was assayed spectrophotometrically by the rate of increase in absorbance at $550 \mathrm{~nm}\left(\mathrm{at}+10^{\circ} \mathrm{C}\right)$ of cytochrome $c$. The reaction mixture consisted of $0.3 \mathrm{M}$ phosphate buffer, $\mathrm{pH} 7.7,0.1 \mathrm{mM}$ $\mathrm{NADPH}, 0.1 \mathrm{mM}$ EDTA, $1 \mathrm{mM} \mathrm{KCN}$, and $50 \mu \mathrm{M}$ cytochrome $c$ (Strobel and Dignam, 1978). Cytochrome P-450 content was measured according to Estabrook and Werringloer (1978). Protein was determined by the method of Hartree (1972) with bovine serum albumin as a standard. All analyses were performed in duplicate. All reactions were linear with respect to time and protein concentration.

\section{Solubilization of microsomes}

It was achieved by using several ionic (CHAPS and sodium cholate) and non-ionic detergents (Lubrol PX, Renex 690, Emulgen 911 and 913). Microsomes were solubilized with each detergent (final concentration: $0.5 \%$ ) in a medium containing $1 \mathrm{mM}$ DTT, $0.1 \mathrm{mM}$ phosphate buffer $\mathrm{pH} 7.4,20 \%$ glycerol, and $1.6 \mathrm{mg}$ of protein $/ \mathrm{ml}$ at $+4^{\circ} \mathrm{C}$ The mixture was stirred for $30 \mathrm{~min}$, then centrifuged at $105,000 \mathrm{~g}$ for $60 \mathrm{~min}$. The content of cytochrome P-450 in the supernatant fraction and in the microsomes was determined as above.

\section{RESULTS}

The components of the MO system and the MO activities in nase and roach are shown in Table 1 . The level of cytochrome P-450 and the associated activities were higher in nase than in roach.

The optimal $\mathrm{pH}$ for MO activity was 7.2 (AHH, both species), 7.0 and 7.4 (PPOH, nase and roach, respectively), 7.4 and 7.6 (7-ECOD, nase and roach, respectively), and 7.8 (7-EROD, both species) (Fig. 1). However, the activities measured at optimal pH represent only $100-125 \%$ of the corresponding activities measured at $\mathrm{pH} 7.4$, thus we have routinely used the latter value for all determinations.

Temperature dependency showed two distinctly different patterns according to the substrate (Fig. 2). The highest $\mathrm{MO}$ activity for both species was found at $30^{\circ} \mathrm{C}$ for $\mathrm{AHH}, \mathrm{PPOH}$ and $7-\mathrm{ECOD}$. In contrast, 7-EROD activity was maximal at $10^{\circ} \mathrm{C}$ for roach and $20^{\circ} \mathrm{C}$ for nase.

Cofactor requirements for MO activity were compared with liver microsomes from rat, nase and roach (Table 2). NADPH was an obligatory component for activity. Relative to NADPH, NADH was a poor source of electrons, and sustained the studied reactions at a very low rate, with the exception of rat liver 7-EROD. When both NADPH and NADH were present, some synergism was observed, especially for $\mathrm{AHH}$ and $\mathrm{PPOH}$ activities. Addition of $\mathrm{Mg}^{2+}$ ions does not modify 7-ECOD, $\mathrm{AHH}$ and $\mathrm{PPOH}$ activities, but strongly depresses rat liver 7-EROD activity.

$\alpha$-Naphthoflavone and metyrapone are wellknown inhibitors of $\mathrm{MO}$ activities. The only exceptions were rat liver AHH which was slightly activated by $\alpha$-naphthoflavone, and nase liver $\mathrm{AHH}$ which was slightly activated by metyrapone (Fig. 3 ). The sensitivity of the four studied reactions toward inhibition by these two diagnostic inhibitors was quite different in the liver microsomal fraction of fish and rat, but no significant differences were found hetween roach and nase. Metyrapone proved to be a more potent inhibitor of reactions catalysed by rat microsomes as compared to fish, whereas $\alpha$-naphthoflavone inhibited more strongly the reactions catalysed by the microsomes of fish compared to those of rat liver, especially at high concentrations of inhibitor.

Table 3 shows the effect of detergents on the solubilization and recovery of cytochrome P.450 from nase and roach liver microsomes. A better recovery was obtained with roach than with nase microsomes. It was also found that the non-ionic detergents and CHAPS were rather interchangeable. On the other hand, sodium cholate was less effective when used to solubilize microsomes from both species. 

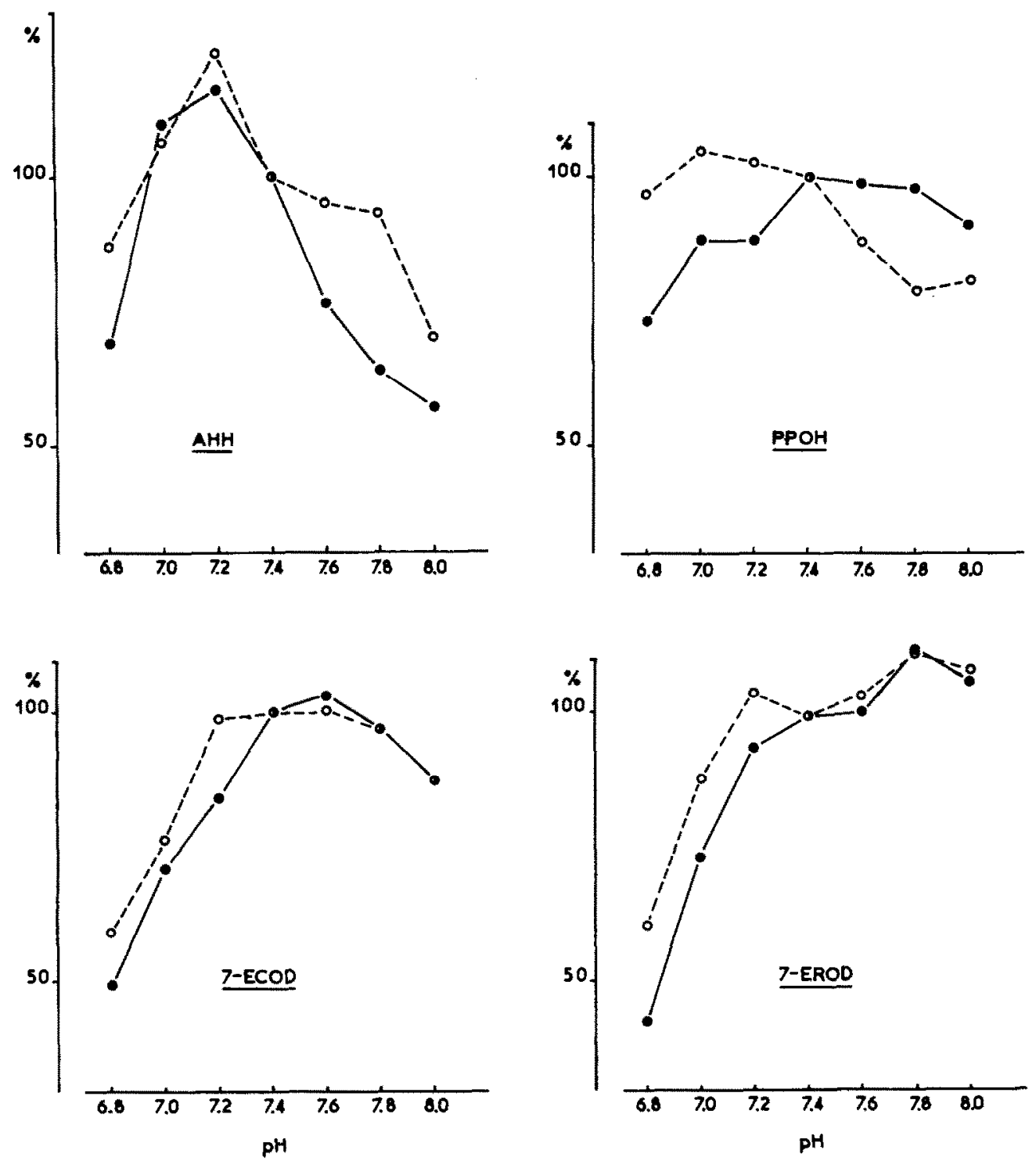

Fig. 1. pH-Dependency of 7-EROD, 7-ECOD, AHH, and PPOH in liver microsomes from nase (O---O) and roach $(-)$ ). Activities are expressed as percentage of specific activity at pH 7.4.

\section{DISCUSSION}

The results presented here showed that liver microsomes from nase and roach were able to metabolize model xenobiotic compounds. Previous studies are rather limited, they include measurements of $N$ demethylation of aminopyrine and $p$-hydroxylation of aniline in roach (DeWaide and Henderson, 1970), hepatic cytochrome $\mathrm{P}-450$ concentration in roach (Koivusaari et al., 1980), cytochrome P-450, 7-ECOD, AHH and UDP-glucuronosyltransferase activities in roach (Lindström-Seppä et $a l ., 1981$ ), and AHH in nase (Kezić et al., 1983) and roach (Ahokas and Pelkonen, 1984). A lower cytochrome P-450 content $(0.089 \mathrm{nmol} / \mathrm{mg}$ of protein) and 7-ECOD activity $(0.019 \mathrm{nmol} / \mathrm{mg}$ of protein $/ \mathrm{min})$ were found in roach by Lindström-Seppä et al. (1981). These results emphasize the wide range of enzymatic activities found in wild species collected from different sites. However, when 7-ECOD activity is expressed on the basis of cytochrome P-450 concentration, the latter result $(0.21 \mathrm{nmol} / \mathrm{nmol}$ cytochrome $\mathrm{P}-450 / \mathrm{min})$ closely relates to our data $(0.19 \mathrm{nmol} / \mathrm{nmol}$ cytochrome P-450/min).

The electron donor requirements are consistent with cytochrome P-450-dependent reactions which resemble that of fish and mammals. It is interesting to notice that NADH can be a useful electron donor for aminopyrine $N$-demethylase in scup (Stegeman et al., 1979) and in trout (Koivusaari, 1984), but not for 7-EROD and 7-ECOD in trout (Koivusaari, 1984). The partial involvement of NADH in 7-EROD activity in rat was also found by Burke and Mayer (1974).

Some differences in $\mathrm{pH}$ dependence were seen with 

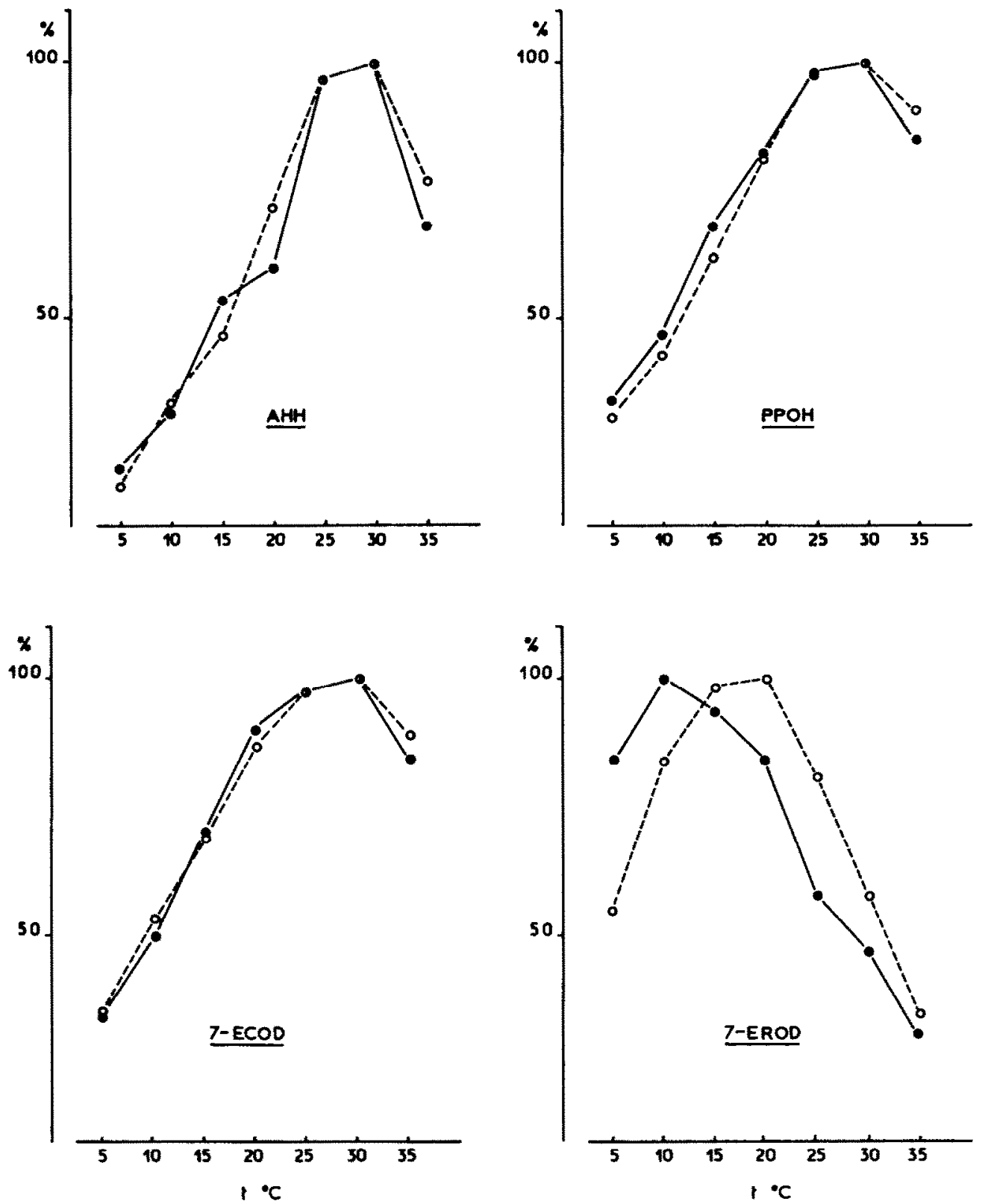

Fig. 2. Temperature dependency of 7-EROD, 7-ECOD, AHH, and PPOH in liver microsomes from nase $\left(\mathrm{O}_{--} \mathrm{O}\right)$ and roach $(-$ ). Activities are expressed as percentage of maximal activity.

fish microsomes using different species and different substrates. The most studied activity was AHH which showed an optimum at $\mathrm{pH} 7.4$ with rainbow trout microsomes (Pedersen et al., 1974) and a broad peak of activity between 6.8 and 8.0 with scup microsomes (Stegeman et al., 1979). 7-EROD activity usually

Table 2. Cofactor requirements for monooxygenase activities in liver microsomes from rat, nase and roach*

\begin{tabular}{|c|c|c|c|c|c|c|c|c|c|c|c|c|}
\hline \multirow{2}{*}{$\begin{array}{l}\text { Cofactor } \\
\text { (1 } \mathrm{mM})\end{array}$} & \multicolumn{3}{|c|}{ 7-ECOD } & \multicolumn{3}{|c|}{ 7-EROD } & \multicolumn{3}{|c|}{ AHH } & \multicolumn{3}{|c|}{ PPOH } \\
\hline & Rat & Nase & Roach & Rat & Nase & Roach & Rat & Nase & Roach & Rat & Nase & Roach \\
\hline 0 & 0 & 0 & 0 & 0 & 2.5 & 0 & 0 & 0 & 0 & 0 & 0 & 0 \\
\hline NADPH & 100 & 100 & 100 & 100 & 100 & 100 & 100 & 100 & 100 & 100 & 100 & 100 \\
\hline NADH & 18 & 12 & 8 & 28 & 14 & 5 & 4 & 8 & 4 & 9 & 16 & 9 \\
\hline $\mathrm{NADPH}+\mathrm{NADH}$ & 115 & 108 & 112 & 107 & 102 & 102 & 123 & 130 & 109 & 130 & 117 & 139 \\
\hline $\mathrm{NADPH}+\mathrm{MgCl}_{2}$ & 105 & 100 & 102 & 60 & 94 & 94 & 101 & 108 & 95 & 101 & 106 & 122 \\
\hline
\end{tabular}

Microsomes were incubated with the above cofactors as indicated in Materials and Methods. Results are shown as a percentage of NADPH (generating system)-supported activity 

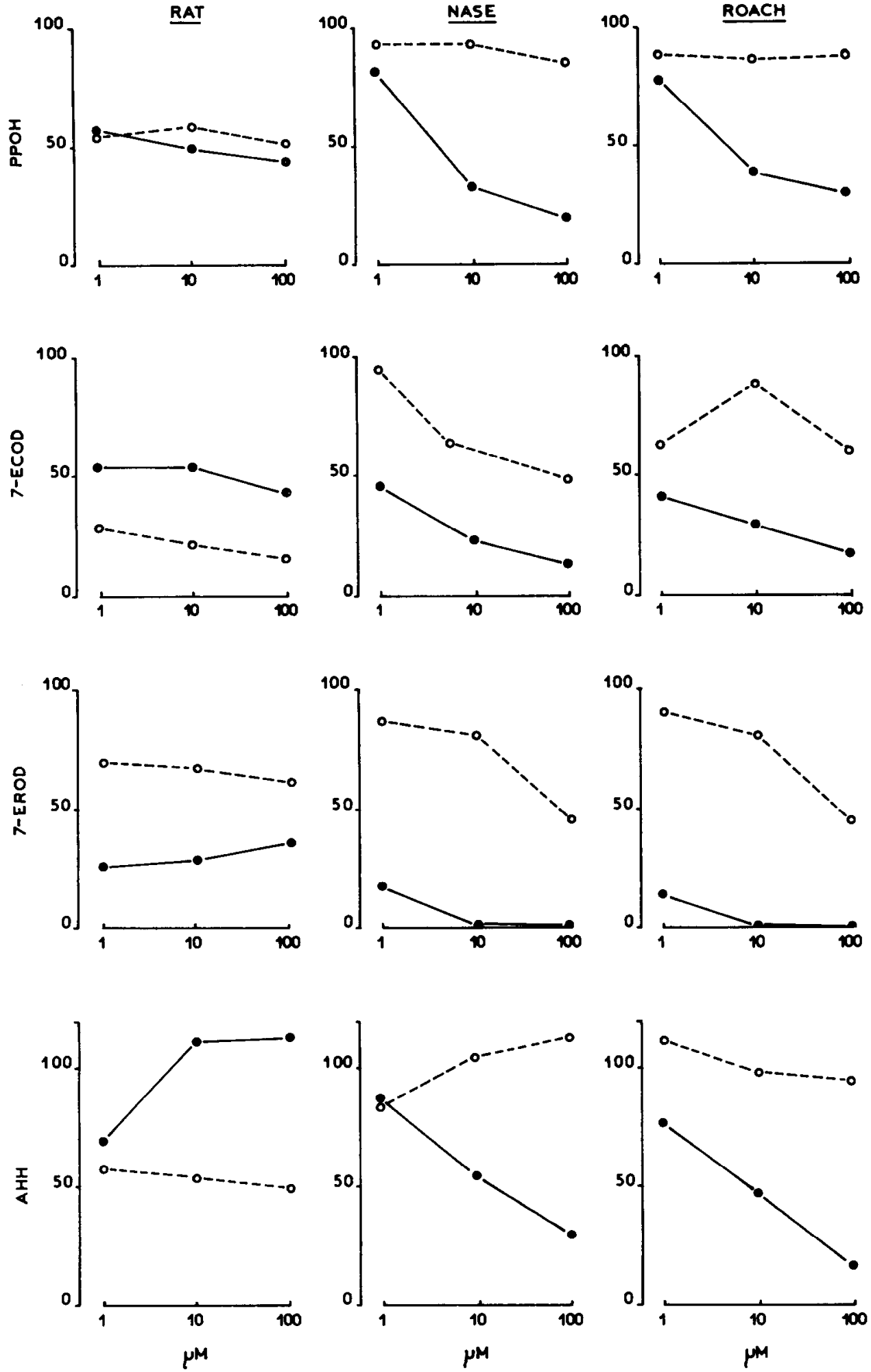

Fig. 3. In vitro inhibition of 7-EROD, 7-ECOD, $\mathrm{AHH}$, and $\mathrm{PPOH}$ by metyrapone (O--O) and $\alpha$-naphthoflavone (-) at various concentrations in liver microsomes from rat, nase, and roach. Inhibitors were added in $10 \mu 1$ of DMSO. The results are expressed as percentage remaining enzyme activity compared to a DMSO-treated sample. 
Table 3. Solubilization of cytochrome P. 450 with various detergents from roach and nase liver microsomes

\begin{tabular}{lcc}
\hline & Nase & Roach \\
\hline Emulgen 911 & $83^{*}$ & 89 \\
Emulgen 913 & 79 & 88 \\
Cholate Na & 40 & 29 \\
CHAPS & 76 & 88 \\
Lubrol PX & 70 & 97 \\
Renex 690 & 84 & 94 \\
\hline Percentage of recovery of cyto- \\
chrome P-450 in supernatant \\
(see Materials and Methods) \\
relative to original microsomes. \\
Each value represents the mean \\
of two determinations.
\end{tabular}

shows a $\mathrm{pH}$ dependence with a peak rate between $\mathrm{pH}$ 7.8 and 8.0 in rat (Burke and Mayer, 1974) and fish (Klotz et al., 1984).

The optimal incubation temperature of $30^{\circ} \mathrm{C}$ for AHH, PPOH and 7-ECOD activities from nase and roach is consistent with those reported for a variety of fish (DeWaide and Henderson, 1968; Pohl et al., 1974; Elcombe and Lech, 1979; Schwen and Mannering, 1982). 7-EROD was a striking exception showing a distinct pattern with an optimal temperature of $20^{\circ} \mathrm{C}$ (nase) and even $10^{\circ} \mathrm{C}$ (roach). With trout microsomes, the maximum activity of 7-EROD was found at $20-25^{\circ} \mathrm{C}$, but in the range of $10-15^{\circ} \mathrm{C}$, close to the environmental temperature $\left(12^{\circ} \mathrm{C}\right)$, the activity was still $90-95 \%$ of the maximum activity (Williams et al., 1983). The exact causes for such different patterns should be found in the nature of the lipid components surrounding the active site of cytochrome P-450 (Gurumurthy and Mannering, 1985; Williams et al., 1983; Hagar and Hazel, 1985). Obviously, these findings emphasize clearly the need for measuring $\mathrm{MO}$ activities in poikilothermic animals at environmental temperatures to obtain realistic values.

In nase and roach, inhibition of MO activities by metyrapone was less pronounced than in untreated rats. Previous studies have shown that this compound inhibited AHH activity in hepatic microsomes from control and phenobarbital-induced mice (Goujon et al., 1972), but no inhibition was found in hepatic microsomes from carp (Melancon et al., 1981) and rainbow trout (Elcombe and Lech, 1979). The inhibitory effect of $\alpha$-naphthoflavone on hepatic microsomal AHH from nase and roach is similar to that observed in control and $\beta$-naphthoflavone-treated rainbow trout (Statham et al., 1978; Elcombe and Lech, 1979), control lake trout (Ahokas et al., 1975), control scup (Stegeman et al., 1979), control and both polychlorobiphenyl- and $\beta$-naphthoflavone-induced carp (Melancon et al., 1981) and polycyclic aromatic hydrocarbon-induced rat (Wiebel et al., 1971). On the other hand, $\alpha$-naphthoflavone stimulates AHH activity in microsomes from control rat (Wiebel et al., 1971), control little skate (Bend et al., 1977), control sheepshead (Bend and James, 1978). In mammalian species, it is generally believed that phenobarbitalinducible cytochromes $\mathrm{P}-450$ are preferably inhibited by metyrapone, while polycyclic aromatic hydrocarbon-inducible cytochromes $\mathrm{P}-450$ are prefer- ably inhibited by $\alpha$-naphthoflavone (Goujon et al., 1972). Our data are in agreement with earlier studies, suggesting the presence of a "P-448-like" form of cytochrome P-450 in most species of fish.

The solubilization of microsomes is a prerequisite for purification and further characterization of cytochromes P-450. In fish, some problems have been reported with this step (Williams and Buhler, 1982; Klotz et al., 1983). Emulgen 911 and 913 and various non-ionic detergents have been widely used in purification of mammalian enzymes with more than $90 \%$ recovery of cytochrome $\mathrm{P}-450$ (Guengerich, 1982), a recovery of $96 \%$ was obtained with CHAPS (Williams and Buhler, 1982) in solubilizing trout microsomes, and a yield of $73 \%$ was obtained by Goksøyr (1985) by using CHAPS and sodium cholate to solubilize cod microsomes. Our results indicate a good recovery of cytochrome P-450 without appreciable contamination by cytochrome $P-420$ when nase and roach microsomes were solubilized by CHAPS, Emulgens and some other detergents.

Acknowledgements - This work was supported in part by a CNRS/PIREN Program "Maîtrise des ressources ichthy" ologiques". The authors also thank Paul Buisson for providing fish and Corinne Gaulin for technical assistance.

\section{REFERENCES}

Ahokas J. T., Pelkonen O. and Kärki N. T. (1975) Metabolism of polycyclic hydrocarbons by a highly active aryl hydrocarbon hydroxylase system in the liver of a trout species. Biochem. biophys. Res. Commun. 63, 635-641.

Ahokas J. T. and Pelkonen O. (1984) Metabolic activation of polycyclic aromatic hydrocarbons by fish liver cytochrome P-450. Mar. envir. Res. 14, 59-69.

Bend J. R., James M. O. and Dansette P. M. (1977) In vitro metabolism of xenobiotics in some marine animals. Ann. N.Y. Acad. Sci. 298, 505-521.

Bend J. R. and James M. O. (1978) Xenobiotic metabolism in marine and freshwater species. Biochem, biophys, perspect. Mar. Biol. 4, 125-188.

Burke M. D. and Mayer R. T. (1974) Ethoxyresorufin: direct fluorometric assay of a microsomal $O$-dealkylation which is preferentially inducible by 3 -methylcholanthrene Drug Metab. Dispos. 2, 583-588.

Chambers J. E. and Yarbrough J. D. (1976) Xenobiotic biotransformation systems in fishes. Comp. Biochem. Physiol. 55C, 77-84.

DeWaide J. H. and Henderson P. T. (1968) Hepatic N. demethylation of aminopyrine in rat and trout. Biochem. Pharmac. 17, 1901-1907.

DeWaide J. H. and Henderson P. T. (1970) Seasonal variation of hepatic drug metabolism in the roach, Leuciscus rutilus L., Comp. Biochem. Physiol. 32, 489-497.

Elcombe C. R. and Lech J. J. (1979) Induction and characterization of hemoprotein(s) P-450 and monooxygenation in rainbow trout (Salmo gairdneri). Toxic. appl. Pharmac. 49, 437-450.

Estabrook R. W. and Werringloer J. (1978) The measurement of difference spectra: application to the cytochromes of microsomes. In Methods in Enzymology (Edited by Fleischer S. and Packer L.), Vol. 52C, pp. 212-220. Academic Press, New York.

Estabrook R. W., Werringloer J. and Peterson J. A. (1979) The use of animal subcellular fractions to study type I metabolism of xenobiotics. In Xenobiotic Metabolism: In Vitro Methods, ACS Symposium Series 97 (Edited by Paulson G. D., Frear D. S. and Marks E. P.), pp. 149-179. American Chemical Society, Washington D.C. Goksøyr A. (1985) Purification of hepatic microsomal cyto- 
chromes P-450 from $\beta$-naphthoflavone-treated Atlantic cod (Gadus morhua), a marine teleost fish. Biochim. biophys. Acta 840, 409-417.

Goujon F. M., Nebert D. W. and Gielen J. E. (1972) Genetic expression of aryl hydrocarbon hydroxylase induction. IV. Interaction of various compounds with different forms of cytochrome P-450 and the effect on benzo(a)pyrene metabolism in vitro. Molec. Pharmac. 8 , $667-680$.

Guengerich F. P. (1982) Microsomal enzymes involved in toxicology-analysis and separation. In Principles and Methods of Toxicology (Edited by Hayes A. W.), pp. 609-634. Raven Press, New York.

Gurumurthy P. and Mannering G. J. (1985) Membrane bound cytochrome P-450 determines the optimal temperatures of NADPH-cytochrome P-450 reductase and cytochrome $\mathrm{P}-450$-linked monooxygenase reactions in rat and trout hepatic microsomes. Biochem. biophys. Res. Commun. 127, 571-577.

Hagar A. F. and Hazel J. R. (1985) Changes in desaturase activity and the fatty acid composition of microsomal membranes from liver tissue of thermally-acclimating rainbow trout. J. comp. Physiol. 156, 35-42.

Hartree E. F. (1972) Determination of protein: a modification of the Lowry method that gives a linear photometric response. Analyt. Biochem. 48, 422-427.

James M. O., Fouts J. R. and Bend J. R. (1977) Xenobiotic metabolizing enzymes in marine fish. In Pesticides in Aquatic Environments (Edited by Khan M. A. Q.), pp. 171-189. Plenum Press, New York.

Kezić N., Britvić S., Protić M., Simmons J. E., Rijavec M., Zahn R. K. and Kurelec B. (1983) Activity of benzo(a)pyrene monooxygenase in fish from the Sava river, Yugoslavia: correlation with pollution. Sci. tot. Envir. 27, 59-69.

Klotz A. V., Stegeman J. J. and Walsh C. (1983) An aryl hydrocarbon hydroxylating hepatic cytochrome P-450 from the marine fish Stenotomus chrysops. Archs Biochem. Biophys. 226, 578-592.

Klotz A. V., Stegeman J. J. and Walsh C. (1984) An alternative 7-ethoxyresorufin $O$-deethylase activity assay: a continuous visible spectrophotometric method for measurement of cytochrome P-450 monooxygenase activity. Analyt. Biochem. 140, 138-145.

Koivusaari U. (1984) Xenobiotic biotransformation in rainbow trout, Salmo gairdneri, with special reference to seasons and reproduction. Dissertation, University of Kuopio.

Koivusaari U., Lindström-Seppä P., Lang M., Harri $M$. and Hänninen O. (1980) Occurrence of cytochrome P-450 in certain fresh water species in Northern Europe. Devl Biochem. 13, 455-458.

Lech J. J. and Bend J. R. (1980) Relationship between biotransformation and the toxicity and fate of xenobiotic chemicals in fish. Envir. Hlth Persp. 34, 115-131.

Lindström-Seppä $P$., Koivusaari $U$. and Hänninen $O$. (1981) Extrahepatic xenobiotic metabolism in NorthEuropean freshwater fish. Comp. Biochem. Physiol. 69C, 259-263.

Melancon M. J., Elcombe C. R., Vodicnik M. J. and Lech
J. J. (1981) Induction of cytochromes P-450 and mixedfunction oxidase activity by polychlorinated biphenyls and $\beta$-napththoflavone in carp (Cyprinus carpio). Comp. Biochem. Physiol. 69C, 219-226.

Nebert D. W. and Gelboin H. V. (1968) Substrate-inducible microsomal aryl hydroxylase in mammalian cell culture: I. Assay and properties of induced enzyme. J. biol. Chem. 243, 6242-6249.

Pedersen M. G., Hershberger W. K. and Juchau M. R. (1974) Metabolism of 3,4-benzpyrene in rainbow trout (Salmo gairdneri). Bull. envir. contam. Toxicol. 12, 481-486.

Pohl R. J., Bend J. R., Guarino A. M. and Fouts J. R. (1974) Hepatic microsomal mixed-function oxidase activity of several marine species from coastal Maine. Drug Metab. Dispos. 2, 545-555.

Prough R. A., Burke M. D. and Mayer R. T. (1978) Direct fluorometric methods for measuring mixed-function oxidase activity. In Methods in Enzymology (Edited by Fleischer S. and Packer L.), Vol. 52C, pp. 372377 . Academic Press, New York.

Rifkind A. B. and Muschick H. (1983) Benoxaprofen suppression of polychlorinated biphenyl toxicity without alteration of mixed-function oxidase function. Nature, Lond. 303, 524-526.

Schwen R. J. and Mannering G. J. (1982) Hepatic cytochrome P-450-dependent monoxygenase systems of the trout, frog and snake-II. Monooxygenase activities. Comp. Biochem. Physiol. 71B, 437-443.

Statham C. N., Elcombc C. R., Szyjka S. P. and Lech J. J. (1978) Effect of polycyclic aromatic hydrocarbons on hepatic microsomal enzymes and disposition of methylnaphthalene in rainbow trout in vivo. Xenobiotica 8 , $65-71$.

Stegeman J. J., Binder R. L. and Orren A. (1979) Hepatic and extrahepatic microsomal electron transport components and mixed-function oxygenases in the marine fish Stenotomus versicolor. Biochem. Pharmac. 28, 3431-3439.

Strobel H. W. and Dignam J. D. (1978) Purification and properties of NADPH-cytochrome P-450 reductasc. In Methods in Enzymology (Edited by Fleischer $\mathrm{S}$. and Packer L.), Vol. 52C, pp. 89-96. Academic Press, New York.

Ullrich V. and Weber P. (1972) The $O$-dealkylation of 7-ethoxycoumarin by liver microsomes. Hoppe-Seyler's Z. physiol. Chem. 354, 1171-1177.

Wiebel F. J., Leutz J. C., Diamond L. and Gelboin H. V. (1971) Aryl hydrocarbon [benzo(a)pyrene] hydroxylase in microsomes from rat tissues: differential inhibition and stimulation by benzoflavone and organic solvents. Archs Biochem. Biophys. 144, 78-86.

Williams D. E. and Buhler D. R. (1982) Purification of cytochromes $\mathrm{P}-\mathbf{4 4 8}$ from $\beta$-naphthoflavone-treated rainbow trout. Biochem. biophys. Acta 717, 398-404.

Williams D. E., Becker R. R., Potter D. W., Guengerich F. P. and Buhler D. R. (1983) Purification and comparative properties of NADPH-cytochrome P-450 reductase from rat and rainbow trout: differences in temperature optima between reconstituted and microsomal trout enzymes. Archs Biochem. Biophys. 225, 55-65. 